\title{
Endoderm Cell
}

National Cancer Institute

\section{Source}

National Cancer Institute. Endoderm Cell. NCI Thesaurus. Code C33932.

An embryonic cell of the inner layer of three germ layers that forms the yolk sac and gives rise to the epithelium of the alimentary and respiratory tracts and the parenchyma of associated glands. 